\title{
Effect of Incentive Spirometry on Recovery of Post-Operative Patients: Pre Experimental Study
}

\author{
Akashdeep Kaur, C. Vasantha Kalyani, Kusum K* \\ All India Institute of Medical Sciences, Rishikesh, India \\ Corresponding author: kus2211@gmail.com
}

\begin{abstract}
Background: Post-operative care is management of patients after any surgery. The main goal of post-operative care is to prevent complications i.e. atelectasis and infection. The other objective is early healing of the surgical incision and return of patient to a state of health. About $17 \%$ to $88 \%$ of people in postoperative duration will have decreased lung volumes. This decreased lung volume problem can be solved with use of incentive spirometry in postoperative period on Day 1. Incentive spirometer is perioperative respiratory therapy given to postoperative patients to improve lung volume of patients and hasten recovery of patients also.

Purpose: This study aimed to identify effect of Incentive spirometry on postoperative patient's recovery.

Methods: It was pre-experimental study with pretest- posttest design only, which was done on post-operative patients at All India Institute of Medical Sciences (AIIMS), Rishikesh.

Results: Majority (52\%) of participants were 41 to 50 years age group. Male and female ratio for participants were 46:54. Paired ' $t$ ' test $p$ value i.e. $0.00 *$ with CI $[0.72,1.03]$ showed that on Pretest and Day 3 Performance level on incentive spirometry of participants showed a significant value, which indicate that spirometer enhance recovery of post-operative patients by increasing their lung volumes.

Conclusions: This study revealed that incentive spirometry is effective in improving of pulmonary function among post-operative patients, which further improves blood circulation and hasten early recovery of surgical wound. This spirometry should be integral part of Post-operative care. All nurses who are involved in Postoperative units should encourage patients to do it on regular basis and document it as a vital sign. Good compliance to incentive spirometry can improve better outcome of patient's.
\end{abstract}

Keywords: Effectiveness, Incentive spirometry, Post operative Patients, Postoperative Recovery. 


\section{Journal Of Nursing Practice}

http://thejnp.org

ISSN: 2614-3488 (print); 2614-3496 (online)

Vol.3 No.2. April 2020. Page.220-225

\section{BACKGROUND}

Postoperative recovery is main process of being in a state of complete wellness. Postoperative recovery can be achieved by returning of normal health of patient's at a level of independence i.e. activities of daily living patients can do in postoperative patient's as early as possible. It can also be achieved by optimizing psychological well-being of patient's as well (Berg, 2012).

Postoperative care of patients not only includes early mobilization in which deep breathing and coughing exercises should be included to prevent any pulmonary complications. It also include ensuring patient's for adequate nutrition, preventing pressure sores development, frequent turning of patient and adequate pain control in post-operative period. In America about $95 \%$ of hospitals provide incentive spirometer to postoperative patient's prophylactically for treatment of atelectasis and other respiratory problems. Incentive spirometer is a reproducible sustained maximal inspiration, which mainly records frequency and rate of respiration at acceptable rate. Incentive spirometry is also widely used routine clinically procedure for prophylactic and treatment regimen as a perioperative respiratory therapy (Stephens, 2016).

Incentive spirometry is also called as sustained maximal inspiration (SMI) and is considered bronchial hygiene therapy. It mainly designed to function as a natural yawning including long, slow, deep breaths. Incentive spirometry is done by using a device which provides patient's visual and positive feedback when they inhale at a predetermined set volume and inflation should sustain for minimum of 3 seconds (Hilling, 1996).

A systematically review was done to identify effect of incentive spirometry (IS) for prevention of postoperative pulmonary complications (PPCs). A through searching of MEDLINE, CINAHL, HealthSTAR, and Current Contents databases for review. After critical appraisal of information, they searched 85 research articles. In 35 of these studies they were unable to accept the stated conclusions. Critical appraisal of remaining 11 remaining studies indicated in 10 studies, there was no positive short-term effect of incentive spirometry in cardiac or abdominal surgery. The only supportive study reported that incentive spirometry, deep breathing and intermittent positive-pressure breathing were equally more effective than no treatment in preventing postoperative pulmonary complications following abdominal surgery. So Incentive spirometry showed significantly effective in preventing postoperative pulmonary complications in abdominal surgery patients (Overend, 2001).

Research studies on incidence of postoperative complications occurrence showed $61 \%$ patients develop complication after discharge from hospital. The four main problem faced by patients at home were surgical site infection (SSI), urinary infections, functional gastrointestinal problems, and pain management problems after discharge. The main problem in postoperative periods in hospital were cardiac, respiratory, and neurologic complications. So incentive spirometry can be very useful to prevent respiratory complications in postoperative periods (Woodfiel, 2016).

Anaesthesia has a major effect on pulmonary functions which may continue on postoperative period. General Anaesthesia mainly exhibits its effects by changes in respiratory mechanic. Pulmonary functions are equally affected by anaesthetic agent used for anaesthesia, thus long term effects are changes in lung volumes, airway resistance and respiratory compliances, which alter V/Q ratio. Pulmonary functions can be properly address to prevent potential complications during anaesthesia, after anaesthesia and in post-operative period. As incentive spirometry is helpful to improve pulmonary function of patients. So 


\section{Journal Of Nursing Practice}

http://thejnp.org

ISSN: 2614-3488 (print); 2614-3496 (online)

Vol.3 No.2. April 2020. Page.220-225

incentive spirometry can help in over these side effect in postoperative period (Saraswat, $\underline{2015)}$

As incentive spirometry is helpful to prevent postoperative pulmonary complications but there was lack of evidence about its effectiveness in postoperative recovery among surgical patients.

\section{OBJECTIVE}

This study aimed to check effect of incentive spirometry on postoperative recovery and asses and compare effect of incentive spirometry on postoperative performance level among post-operative patients.

\section{METHODS}

Study Design used for research was pre-experimental study with pretest- posttest design. Sampling technique were non-probability purposive sampling. Study setting used in study were surgical IPD's of AIIMS, Rishikesh. Study participants were post-operative patients of general surgery IPD who are advised for incentive spirometry.

\section{Formula used for sample size calculation were:}

$$
n=\frac{\left(1-\frac{\mathrm{n}}{\mathrm{N}}\right) \times \mathrm{t}^{2}(\mathrm{p} \times \mathrm{q})}{\mathrm{d}^{2}}
$$

$\mathrm{n}=$ Sample size, $\mathrm{N}=$ Size of the eligible population.

$t^{2}=$ Square value of the standard deviation score that refer to the area under a normal distribution of values.

$\mathrm{p}=$ Percentage category for which we are computing the sample size, $q=(1-\mathrm{p})$

$d^{2}=$ Square value of one half to the precision internal around the sample estimate.

Sample size were 50 patients who undergone for any surgery.

Description of Data collection tools: Data collection tools consist of two parts. Part I consist of socio-demographic variable including age, gender, diagnosis. Part II consist of Observation checklist in which patients were observed when they were doing incentive spirometry (Take 15 breaths with spirometer in every 2 hours) ${ }^{(7)}$ on Day 1, 2 and 3 and check their performance level i.e. Score=0, Not able to perform, Score=1 means Inadequate, Score $=2$ means Moderately Adequate and Score $=3$ meaning Adequate performance.

Procedure of Incentive Spirometry used in study were:

1. Sit in bed and hold the device.

2. Place mouthpiece of spirometer in mouth.

3. Always make sure that you are making a good seal on mouthpiece with lips.

4. Breath out (exhale) normally.

5. Then Breath in (inhale) slowly. The ball in the incentive spirometer will rise as you breathe in.

6. Try to get this ball to rise as high as you can.

7. Take 15 breaths with spirometer in every 2 hours (MedlinePlus, 2019).

8 . Repeats this procedure in every 2 hourly and document it.

Schedule for incentive spirometry were $6 \mathrm{am}, 8 \mathrm{am}, 10 \mathrm{am}, 12$ noon, $2 \mathrm{pm}, 4 \mathrm{pm}, 6 \mathrm{pm}$ with 15 breaths in every 2 hours. The Pretest observation were recorded before starting of incentive spirometry and then for three consecutive days data recording were collected in above following the schedule.

Data analysis were done by using descriptive statistics and inferential statistics. For socio-demographic data frequency and percentage were calculated. Chi square test was used 


\section{Journal Of Nursing Practice}

http://thejnp.org

ISSN: 2614-3488 (print); 2614-3496 (online)

Vol.3 No.2. April 2020. Page.220-225

to find relationship of socio-demographic variables with pre-test and post-test results. T test was applied to identify difference between pre-test and post test results.

\section{RESULTS}

In this study, Data was collected from 50 participants, which were from various surgery IPD departments.

Finding related to Socio-demographic Variables: Majority (52\%) of participants were 41 to 50 years age group. Male and female ratio for participants were 46:54. Majority of participants i.e. $68 \%$ who were observed were having below umbilicus surgery. (Table 1)

Table 1. Frequency and percentage of Socio-demographic Variables $\mathbf{N}=\mathbf{5 0}$

\begin{tabular}{|c|c|c|c|c|}
\hline Sr. No. & Variable & Options & Frequency & Percentage \\
\hline \multirow[t]{4}{*}{1.} & \multirow[t]{4}{*}{ Age } & 18-30 years & 2 & 4 \\
\hline & & $31-40$ years & 16 & 32 \\
\hline & & $41-50$ years & 26 & 52 \\
\hline & & $51-60$ years & 6 & 12 \\
\hline \multirow[t]{2}{*}{2.} & \multirow[t]{2}{*}{ Sex } & Male & 23 & 46 \\
\hline & & Female & 27 & 54 \\
\hline \multirow[t]{3}{*}{3.} & \multirow[t]{3}{*}{ Diagnosis } & $\begin{array}{l}\text { Above Umbilicus } \\
\text { Surgery }\end{array}$ & 15 & 30 \\
\hline & & $\begin{array}{l}\text { Below Umbilicus } \\
\text { Surgery }\end{array}$ & 34 & 68 \\
\hline & & $\begin{array}{l}\text { Extremities } \\
\text { Surgery }\end{array}$ & 1 & 2 \\
\hline
\end{tabular}

Finding related to association by using Chi square test: Chi square value $\left(0.003^{*}\right)$ showed significant association of diagnosis with performance level on Incentive spirometry on Pre-test. So there is a strong association between diagnosis for surgery with performance level on Incentive spirometry on Pre-test i.e. about 21 participants who were having below umbilicus surgery showed moderately adequate performance level on Incentive spirometry on Pre-test. Chi square value $\left(0.039^{*}\right)$ also showed significant association of sex with performance level on Incentive spirometry on Day 3 after surgery. So there is a strong association between sex of participants with performance level on Incentive spirometry on Day 3 after surgery i.e. about 21 participants who were female showed adequate performance level on Incentive spirometry on Day 3 after surgery. (Table 2)

Table 2. Chi square value for Diagnosis and Performance level on Incentive spirometry of patients on Pretest and Sex and Performance level on Incentive spirometry of patients on Day 3 after surgery. $N=50$

\begin{tabular}{|l|l|l|l|l|l|}
\hline & \multicolumn{4}{|l|}{ Performance level on Incentive spirometry on Pretest } \\
\hline Diagnosis & $\begin{array}{l}\text { Adequ } \\
\text { ate }\end{array}$ & $\begin{array}{l}\text { Moderately } \\
\text { Adequate }\end{array}$ & Inadequate & $\begin{array}{l}\text { Pearson } \\
\text { Chi-square }\end{array}$ & $\begin{array}{l}\text { Asymp. Sig. } \\
\text { (2-sided) }\end{array}$ \\
\hline $\begin{array}{l}\text { Above Umbilicus } \\
\text { Surgery }\end{array}$ & 0 & 6 & 9 & $16.223^{\mathrm{a}} \mathrm{df}=4$ & $0.003^{*}$ \\
\cline { 1 - 4 } $\begin{array}{l}\text { Below Umbilicus } \\
\text { Surgery }\end{array}$ & 4 & 21 & 10 & & \\
\hline
\end{tabular}




\begin{tabular}{|l|l|l|l|l|l|}
\hline & \multicolumn{5}{|l|}{ Performance level on incentive spirometry on Day 3 } \\
\hline Sex & $\begin{array}{l}\text { Adequ } \\
\text { ate }\end{array}$ & $\begin{array}{l}\text { Moderately } \\
\text { Adequate }\end{array}$ & Inadequate & $\begin{array}{l}\text { Pearson } \\
\text { Chi-square }\end{array}$ & $\begin{array}{l}\text { Asymp. Sig. } \\
\text { (2-sided) }\end{array}$ \\
\hline Male & 10 & 12 & 1 & $6.507^{\mathrm{a}} \mathrm{df}=2$ & $0.039^{*}$ \\
\hline Female & 21 & 5 & 1 & & \\
\hline
\end{tabular}

Finding related to test of Difference by using paired ' $t$ ' test : Paired ' $t$ 'test $p$ value i.e. $0.00 *$ with CI $[0.72,1.03]$ showed that on Pre-test and Day 3 performance level on incentive spirometry of participants showed a significant difference, which means spirometer enhance post-operative performance level on incentive spirometry of patients. (Table 3) Paired ' $t$ ' test $p$ value i.e. $0.00^{*}$ with CI $[0.32,0.63]$ also showed a difference in Pre-test and Day 2 performance level on incentive spirometry of participants. So spirometer enhance post-operative performance level on incentive spirometry of patients. (Table 4)

Table 3. Paired ' $t$ ' test $p$ value with Performance level on Incentive spirometry of patients on Pre-test and Day 3 after surgery. $N=50$

\begin{tabular}{|l|l|l|l|l|l|l|l|}
\hline Days & Mean & $\begin{array}{l}\text { Mean } \\
\text { difference }\end{array}$ & SD $^{\text {D }}$ & SE $^{\text {Mean }}$ & $\begin{array}{l}\text { 95 \% } \\
\text { Confidence } \\
\text { Interval } \\
(\text { CI) }\end{array}$ & $\begin{array}{l}\text { t } \\
\text { value }\end{array}$ & p value \\
\cline { 1 - 6 } Pretest & 1.42 & 0.88 & 0.558 & 0.078 & {$[0.72,1.03]$} & 11.143 & $0.00^{*}$ \\
\cline { 1 - 6 } 3 & 2.30 & & & & \\
\hline
\end{tabular}

Table 4. Paired ' $t$ ' test $p$ value with Performance level on Incentive spirometry of patients on Pre-test and Day 2 after surgery. $\mathrm{N}=50$

\begin{tabular}{|l|l|l|l|l|l|l|l|}
\hline Days & Mean & $\begin{array}{l}\text { Mean } \\
\text { difference }\end{array}$ & SD $^{\text {D }}$ & SE $^{\text {Mean }}$ & $\begin{array}{l}\text { 95 \% } \\
\text { Confidence } \\
\text { Interval } \\
(\mathbf{C I})\end{array}$ & $\begin{array}{l}\text { t } \\
\text { value }\end{array}$ & p value \\
\cline { 1 - 6 } Pre-test & 1.42 & 0.40 & 0.543 & 0.076 & {$[0.32,0.63]$} & 6.244 & $0.00^{*}$ \\
\cline { 1 - 5 } 2 & 1.82 & & & & & \\
\hline
\end{tabular}

\section{DISCUSSION}

This study revealed that incentive spirometry is effective in improving of pulmonary function among the post-operative patients, which further improves blood circulation and hasten early recovery of surgical wound. This spirometry should be integral part of Postoperative care. All nurses who are involved in Postoperative units should encourage patients to do it on regular basis and document it as a vital sign. Good compliance to incentive spirometry can improve better outcome of patient's (Haeffener, 2008)

\section{CONCLUSION}

Majority (52\%) of participants belongs to middle age group. Majority of participants i.e. $68 \%$ recruited were have below umbilicus surgery. Patients having below umbilicus surgery showed moderately adequate performance level on Incentive spirometry on Day 1 after surgery i.e faster recovery in below umbilicus surgery patients. Female patients 


\section{Journal Of Nursing Practice}

http://thejnp.org

ISSN: 2614-3488 (print); 2614-3496 (online)

Vol.3 No.2. April 2020. Page.220-225

showed adequate performance level on Incentive spirometry on Day 3 after surgery. Spirometer enhance performance of postoperative patients on incentive spirometry on Pre-test and Day 3 and Pre-test and Day 2 also.

\section{CONFLICT OF INTEREST DISCLOSURE}

Nil

\section{SOURCE OF FUNDING}

No Funding was taken from any agency for this research project.

\section{ETHICAL CONSIDERATIONS}

Ethical approval were taken Institutional Ethical Committee. (114/IEC/SRS/2017). During recruitment, from each participant written informed consent were taken for study.

\section{REFERENCES}

Berg, K., Kjellgren, K., Unosson, M., \& Årestedt, K. (2012). Postoperative recovery and its association with health-related quality of life among day surgery patients. $B M C$ nursing, 11(1), 24. https://dx.doi.org/10.1186\%2F1472-6955-11-24

Haeffener, M. P., Ferreira, G. M., Barreto, S. S. M., Arena, R., \& Dall'Ago, P. (2008). Incentive spirometry with expiratory positive airway pressure reduces pulmonary complications, improves pulmonary function and 6-minute walk distance in patients undergoing coronary artery bypass graft surgery. American heart journal, 156(5), 900-e1. https://doi.org/10.1016/j.ahj.2008.08.006

Hilling, L., Bakow, E., Fink, J., Kelly, C., \& Southorn, P. A. (1996). Incentive Spirometry. International anesthesiology clinics, 34(1), 57-62.

MedlinePlus. (2019). Using an incentive spirometer. December 24, 2019. from https://medlineplus.gov/ency/patientinstructions/000451.htm.

Overend, T. J., Anderson, C. M., Lucy, S. D., Bhatia, C., Jonsson, B. I., \& Timmermans, C. (2001). The effect of incentive spirometry on postoperative pulmonary complications: a systematic review. Chest, 120(3), 971-978. https://doi.org/10.1378/chest.120.3.971

Saraswat, V. (2015). Effects of anaesthesia techniques and drugs on pulmonary function. Indian journal of anaesthesia, 59(9), 557. https://dx.doi.org/10.4103\%2F0019$\underline{5049.165850}$

Stephens, C. (2016). Postoperative Care. December 23, 2019, from https://www.healthline.com/health/postoperative-care.

Woodfield, J. C., Jamil, W., \& Sagar, P. M. (2016). Incidence and significance of postoperative complications occurring between discharge and 30 days: a prospective cohort study. Journal of Surgical Research, 206(1), 77-82. https://doi.org/10.1016/j.jss.2016.06.073 